\title{
Quality of milk available at local markets of Muktagacha upazila in Mymensingh district
}

\author{
M. A. Islam*, M. H. Rashid, M. F. I. Kajal, and M. S. Alam \\ Department of Dairy Science, Bangladesh Agricultural University, Mymensingh-2202, Bangladesh \\ *E-mail: akhirulshah20@gmail.com
}

\begin{abstract}
The present experiment was conducted to detect quality and level of the adulteration in milk collected from Dharchuni, Atani and Khamar bazar of Muktagacha Upazilla. Organoleptic parameters used to monitor the status of milk samples were color, flavor, taste, texture; physical parameter used was specific gravity; chemical parameters used were acidity, fat content, protein content, lactose content, ash, total solids, solids-not-fat; and the adulteration test used were starch test and formalin test. The tested milk samples showed significantly differences $(p<0.05)$ for specific gravity, protein, fat, lactose and TS contents. No significant difference $(p>0.05)$ were found for \%acidity, ash content, and SNF content of milk samples. Milk collected from Khamar Bazar was higher for protein and fat contents than other markets. Adulteration tests, for all the samples were found negative. Although, there were some fluctuations among the parameters of milk samples regarding standard values; all of the milk samples were found to be acceptable.
\end{abstract}

Keywords: Milk quality, Market, Adulteration

\section{Introduction}

Milk is defined as the whole, fresh, clean, lacteal secretion obtained by complete milking of one or more healthy animals excluding that obtained within fifteen days before or five days after calving or such periods as may be necessary to render milk practically colostrums free and containing the minimum prescribed percentage of milk fat (3.5\%) and solids not fat (8.5\%) (Goff and Hill, 1993). Milk, if present in its natural form has high food value. It supplies nutrients like good quality proteins, fat, carbohydrate, vitamins and minerals in significant amount than any other single food (Neumann et al., 2002). Besides, due to its general need for human health, milk proteins supply those amino acids which are needed for proper growth of adults and infants.

The protein of milk is not a single compound but includes three major proteins namely: casein ( $80 \%$ of total protein) and lactalbumin (18\%) and lactoglobulin (2\%). The essential amino acids like tryptophan and lysine are present in large quantity in milk, which are deficient in vegetable protein. Milk fat is commonly the most valuable constituent of milk. It has a special significance in nutrition, due to the presence of wide range of fatty acids and high content of short chain volatile fatty acids. It is easily digestible and serves as the concentrated source of energy and each gram of fat furnishes 9 calories of energy. It is a carrier of fat-soluble vitamins and helps in lactose assimilation. Calcium and phosphorus, which are important for the formation of bones and teeth and almost all the essential minerals needed by the body are present in the milk. Calcium aids in the construction and relaxation of heart muscles, clotting of blood to prevent fetal bleeding and maintain buffer capacity of blood. Milk is also a rich resource of all known vitamins, which are essential for human health and nutrition. Consumers want safe, wholesome and nutritious milk that is produced and processed in a sound sanitary manner and free from microbial pathogens. The nutritive value of milk depends on its freshness, cleanliness, purity and wholesomeness. It is a consumer demand that time intervals between milk collections from the small holder farmers be short and that delivery to the consumers is ensured to guarantee fresh, clean, pure and wholesome milk.

The supplied milk in Bangladesh is generally found adulterated (Islam et al. 1984). On the other hand, milk is also an excellent media for the growth of micro-organisms. Scouring of milk, discoloration, gassiness and many other defects are caused due to presence and action of various microorganisms. In Bangladesh milk is usually supplied to the consumers in both urban and rural areas by the milk-vendors or Goalas. They collect milk from different small dairy farms as well as from the local markets. The supplied milk is generally found adulterated. Haasnoot et al. (2004) showed that milk adulteration, poor 
hygiene, malpractices, lack of preservation technology, cooling facilities and sanitation are the main cause of losses in quantity of milk. This adulterated milk may cause various diseases to the consumers. The major ways of adulteration of milk are addition of water, flour, sugar, and may be the addition of formalin for preservation of milk. For this reason technical knowledge is important to examine adulterated milk. Hence this study was conducted to detect the adulteration of milk in the Mukthacha upzilla of Mymensingh district.

\section{Materials and Methods}

\section{Collection of sample}

Individual raw milk samples were collected from different local markets of Muktagacha upazilla in the mymensingh district. The selected markets were: $\mathrm{A}=$ Dharchuni bazar, $\mathrm{B}=$ Atani bazar, and $\mathrm{C}=$ Khamar Bazar. Before collection, milk-carrying containers were cleaned and dried properly. Samples were collected 3 times from 3 different local markets and each time 3 samples were collected. These samples were analyzed in the laboratory during the experimental period.

\section{Analysis of the samples}

The following tests were performed on each milk sample to monitor their quality:

1. OrganolepticTest: color, flavor, taste, and texture.

2. Chemical tests: Acidity and ash test as per method as AOAC (2003). Fat content (Herreid, 2008). Protein content ( Horwitz, 1975). The solids not fat (SNF) and total solids (TS) were determined according to Eckles et al (1951). Lactose was determined by reduction method.

3. Physical test: Specific gravity: Aggarwala and Sharma (196l).

4. Test for adulteration: Starch test and Formalin test.

\section{Statistical analysis}

Data were analyzed using one way analysis of variance test by Completely Randomized Design (CRD). Duncan multiple range test (DMRT) method was used to rank the samples.

\section{Results and Discussion}

\section{Organoleptic parameters}

The results for organoleptic parameters of milk samples obtained from the three markets are presented in the Table 1. There were non-significant differences among the organoleptic parameters like color, flavor, taste and texture of milk samples.

\section{Color}

The color score of milk samples are presented in Table 1. The color of all the milk samples from three different local markets Dharchuni, Atani and Khamar Bazar were golden yellowish, yellowish white and whitish in color. This difference in color may be due to the differences in nature of feed, milking in the afternoon, the breed, and the fat and solids contents of the milk. A lot of results were also reported that due to high Carotene; milk imparts a yellowish in color. Amin (2005) showed that the color of the milk sample from four different shops were golden yellowish in color.

\section{Flavor}

The flavors score of milk are presented in (Table 1). It was found that milk samples collected from Dharchuni, Atani and Khamar Bazar contained normal flavor (pleasant aromatic flavor). This might be due to the fact that the farmers take hygienic measures during milking and not to allow the cows to eat some sorts of flavored feed prior to or during milking their cows. This result quite similar with the work of Bari (2001) who showed that the milk flavor was normal (pleasant and aromatic) collected from Bangladesh Agricultural University dairy farm, Mymensingh. 
Taste

The taste score of milk samples are presented in Table 1. The taste of all milk samples collected from three different places of Dharchuni, Atani and Khamar Bazar were slightly sweet in taste. Bari (2001) observed normal taste of milk collected from BAU Dairy Farm. The odd taste of the milk may be due to the unhygienic condition where the milking has done, probably holding the milk for a long time, prior to sale, which provide opportunity to develop some micro-organisms which cause some odd taste like sour, bitter etc.

\section{Texture}

The texture score of milk samples are presented in Table 1. All the milk samples collected from different local market of Muktagacha Upazila showed normal texture (free flowing liquid). These results indicates that quality of milk obtained from different local market of Muktagacha Upazila were superior.

Table 1. Organoleptic test score (Mean \pm SD) of milk samples

\begin{tabular}{|c|c|c|c|c|c|}
\hline \multirow{2}{*}{$\begin{array}{l}\text { Maximum } \\
\text { score }\end{array}$} & \multirow[t]{2}{*}{ Grading score } & \multicolumn{3}{|c|}{ Score obtained by different samples } & \multirow{2}{*}{$\begin{array}{c}\text { Level of } \\
\text { significance }\end{array}$} \\
\hline & & Dharchuni Bazar & Atani Bazar & Khamar Bazar & \\
\hline Color 10 & No criticism 8-9 & $8.60 \pm 0.55$ & $8.20 \pm 0.84$ & $7.800 \pm 0.84$ & NS \\
\hline Flavor 10 & No criticism 8-9 & $8.40 \pm 0.55$ & $8.00 \pm 1.00$ & $8.20 \pm 0.84$ & NS \\
\hline Taste 10 & No criticism 8-9 & $7.80 \pm 0.84$ & $7.60 \pm 0.55$ & $8.20 \pm 0.84$ & NS \\
\hline Texture 10 & No criticism 8-9 & $8.00 \pm 0.71$ & $7.80 \pm 0.84$ & $8.40 \pm 0.55$ & NS \\
\hline Total 40 & No criticism 32-36 & $32.8 \pm 2.65$ & $31.60 \pm 3.23$ & $32.60 \pm 3.07$ & NS \\
\hline
\end{tabular}

*= Significant at 5\% level

NS= Non significant.

\section{Chemical parameters}

Acidity: Results of acidity test of raw milk sample collected from Dharchuni, Atani and Khamar Bazar are presented Table 2. It was found that there was no significant differences ( $P>0.05)$ among the means $\%$ acidity of milk samples collected from these places. Generally the acidity of normal milk sample varies within the range of 0.14 to $0.16 \%$. In this experiment, the \%acidity values of $A$ and $C$ types of milk sample were within the normal range, where as type B showed higher acidity. Higher percentage of acidity might be due to microbial activity or enzymatic reaction. Besides acidity of milk collected from different sources depends sometimes on the time required from milking up to receiving milk in that bazar. The higher content of SNF in milk may show slightly higher percentage of acidity and lower contents shows lower acidity. The result of acidity of milk collected from different sources were in agreement with Bari (2001), who found that acidity percentage of milk collected from Mymensingh town was $0.141 \pm 0.03 \%$ and also the average percentage of cow's milk in Bangladesh Agricultural University Dairy Farm was 0.144 \pm 0.01 . Ali (1999) also found that the average of acidity milk samples from Bangladesh Agricultural University Dairy Farm, milk supplied to different student Halls and vendors were $0.15 \%, 0.16 \%$ and $0.15 \%$ respectively. Alam (1998) obtained the acidity of milk sample from AFTAB dairy fresh raw milk was $0.15 \%$.

Fat content: Statistical analysis showed that average fat contents of milk samples (Table 2) collected from different sources differ significantly $P<0.05$. In this experiment the highest value of milk-fat was obtained from the milk from Khamar Bazar. The fat content of milk collected from Atani was lower than the standard fat content. According to the proposed standard of BSTI-2002 the average fat content of milk is at least $35 \mathrm{~g} / \mathrm{kg}$. The average fat content of milk samples collected from Dharchuni and Khamar Bazar does not satisfy the BSTI standard. The low fat content milk collected from Atani Bazar (B) may be due to adulteration with water, which reduces the fat content of milk samples. This might also be due to the skimming or withdrawing of the fat of market milk samples before the milk was presented in the markets for sale. The results are almost similar with the work of Asaduzzaman (2000) who found that milk samples collected from BAU dairy farm had higher fat content $44.35 \mathrm{~g} / \mathrm{k}$ than that of market samples. 
Protein: The protein content of milk samples are presented in Table 2. Statistical analysis showed that the average protein content of milk collected from different markets differ significantly $(p<0.05)$. In this experiment highest value of milk protein was obtained from Khamar Bazar, whereas that of milk from Dharchuni bazar was much lower. The average values of milk protein agree with the work of Hossain (2009) who reported that the average values of protein content was $36.65 \mathrm{~g} / \mathrm{kg}$ from the dairy farm, BAU, Mymensingh.

Lactose: The lactose content of milk samples collected from is shown in Table-2. The mean lactose content of all the samples differed significantly $(p<0.05)$. In this experiment, highest value of lactose was obtained from milk samples of Dharchuni Bazar. The lactose content of milk of Atani Bazar was higher to Khamar. The mean content of lactose of this experiment was higher than Amin (2005) who found that lactose content in milk collected from different sweetmeat shops in Mymensingh town was $38.70 \mathrm{~g} / \mathrm{kg}$.

Ash: The ash content of milk samples are presented in Table 2. The mean ash contents did not differ significantly $(p>0.05)$. The result of this experiment was higher than Amin (2005) who found that the average ash content of Mymensingh town was $6.78 \mathrm{~g} / \mathrm{kg}$.

Total Solids (TS): There were significant $(p<0.05)$ differences between the total solids contents of milk samples of different local markets at Muktagacha Upazilla of Mymensingh district (Table 2). The highest value of total solids was obtained from milk collected from Khamar Bazar and the lowest from Atani bazar. Islam (2006) studied the milk quality of indigenous cows in BAU, dairy farm and found that the average total-solids content of cow's milk was $142.50 \mathrm{~g} / \mathrm{kg}$, which was higher than the findings of this study. Yadav and Saraswat (1982) reported that lower total solids content of market milk could be as low as of $97.50-$ $115.60 \mathrm{~g} / \mathrm{kg}$.

Solids-not-fat (SNF): The SNF percentage of milk samples collected from Dharchuni, Atani and Khamar is presented in Table 2. Statistical analysis showed that no significance $(p>0.05)$. The average SNF content of milk collected from different market were $91.00 \pm 3.4 \mathrm{~g} / \mathrm{kg}$ which agreed with Islam (2006) who reported that the average SNF percentage of milk of local cows was $87.0 \mathrm{~g} / \mathrm{kg}$. Hossain (2009) also showed higher SNF content in milk collected from Bangladesh Agricultural University Dairy Farm which was $98.65 \mathrm{~g} / \mathrm{kg}$.

Specific Gravity: The values of specific gravity of milk collected from Dharchuni, Atani and Khamar Bazar are given in Table 2. Statistical analysis showed that there were significant difference within the mean specific gravity of sample $(p>0.05)$. The result of specific gravity of milk of Dharchuni Bazar

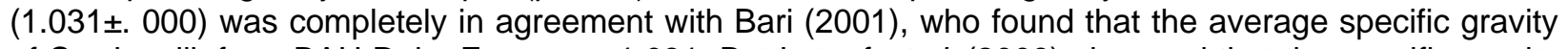
of Cow's milk from BAU Dairy Farm was 1.031. But Lateef et al. (2009) observed that the specific gravity of cow's milk was 1.02 \pm 0.010 ; this may be a slight difference between the samples. The result of mean specific gravity indicates that milk of all places was not adulterated because this could satisfy the normal range of 1.028-1.034 (BSTI-2002).

Table 2. Chemical parameter of milk samples collected from different markets of Muktagacha upazila

\begin{tabular}{|c|c|c|c|c|}
\hline \multirow{2}{*}{ Parameters } & \multicolumn{2}{|c|}{ Milk samples collected from the sources of ( mean \pm SD) } & $\begin{array}{c}\text { Level of } \\
\text { Significance }\end{array}$ \\
\cline { 2 - 5 } & $(\mathrm{A})$ & $(\mathrm{B})$ & $0.160 \pm 0.01$ & $\mathrm{NS}$ \\
\hline Acidity & $0.148 \pm 0.02$ & $0.170 \pm 0.01$ & $49.00^{\mathrm{a}} \pm 5.3$ & $*$ \\
\hline Fat $(\mathrm{g} / \mathrm{kg})$ & $40.33^{\mathrm{ab}} \pm 6.8$ & $32.00^{\mathrm{b}} \pm 2.6$ & $41.83^{\mathrm{a}} \pm 1.9$ & $*$ \\
\hline Protein $(\mathrm{g} / \mathrm{kg})$ & $35.00^{\mathrm{b}} \pm 0.9$ & $40.30^{\mathrm{a}} \pm 2.2$ & $40.90^{\mathrm{b}} \pm 3.1$ & \\
\hline Lactose $(\mathrm{g} / \mathrm{kg})$ & $49.97^{\mathrm{a}} \pm 3.5$ & $44.07^{\mathrm{ab}} \pm 3.6$ & $7.10^{\mathrm{a}} \pm 1.3$ & $\mathrm{NS}$ \\
\hline Ash $(\mathrm{g} / \mathrm{kg})$ & $6.87^{\mathrm{a}} \pm 0.6$ & $8.30^{\mathrm{a}} \pm 1.1$ & $137.00^{\mathrm{a}} \pm 4.6$ & $*$ \\
\hline TS $(\mathrm{g} / \mathrm{kg})$ & $132.67^{\mathrm{ab}} \pm 5.0$ & $124.67^{\mathrm{b}} \pm 4.0$ & $88.00 \pm 2.6^{\mathrm{a}}$ & $\mathrm{NS}$ \\
\hline SNF $(\mathrm{g} / \mathrm{kg})$ & $92.33 \pm 4.0^{\mathrm{a}}$ & $92.67 \pm 1.5^{\mathrm{a}}$ & $1.033 \pm 0.000$ & $*$ \\
\hline Specific gravity & $1.028 \pm 0.000$ & $1.031 \pm 0.000$ & & \\
\hline
\end{tabular}

*= Significant at $5 \%$ level

NS= Non significant 


\section{Tests for Adulteration}

Starch Test: The results for starch test of milk sample collected from Dharchuni, Atani and Khamar of Muktagacha upazila showed negative results. Addition of starch like flour to milk is usually practiced by dishonest venders to hide adulteration by water. The test to detect starch in milk uses iodine solution, addition of which turns the milk solution to blue black color due to the formation of starch-lodo complex in the presence of starch. However, as all of the samples showed negative results. It can be said that there was no added starch.

Formalin test: The results for formalin test of milk sample collected from Dharchuni, Atani and Khamar markets showed negative results. Formalin (40\% Formaldehyde solution) is generally used to preserve biological elements, which is also illegally used to preserve milk for a long time. Formalin is a poisonous chemical that may cause different kinds of disease or may disrupt digestive system. As the Formalin test result was found negative. It could be said that there was no formalin added to milk found at the target markets.

\section{Conclusion}

Milk samples collected from markets of Dharchuni, Atani and Khamar muktagacha upzilla in mymensingh district showed significant differences $(p<0.05)$ for protein, fat, lactose, TS, and Specific gravity of collected samples. No significant differences ( $p>0.05$ ) were found among the acidity, ash, and SNF of milk samples. Milk collected from Khamar Bazar was found to be superior incase of protein and fat contents than those from any other markets. Starch and formalin tests were found negative. There was no adulteration in the milk samples, though there was fluctuation in chemical parameters (fat, protein, ash, and lactose) regarding the standard value.

\section{References}

Aggarwala, A.C. and Sharma, R.M. 1961. A Laboratory Manual of Milk Inspection. 4th Ed. Asia Publilishing House, Bombay, India.

Alam, M.M. 1998. Study on the quality of raw milk produced by individual farmers and mixed milk collected from different centers of four Thana of Kisoregonj district under Aftab Bihumukhi Farm Limited. M. S. Thesis, Department of Dairy Science, Bangladesh Agricultural University, Mymensingh.

Ali, M.S. 1999. A study on the quality of milk consumed by student's different halls and residential people of Bangladesh Agricultural University, Mymensingh. M. S. Thesis, Department of Dairy Science, Bangladesh Agricultural University, Mymensingh.

Amin, M.N. 2005. Studies on the physical and chemical quality of raw milk collected from different sweetmeat shops of Mymensingh town. M. S. Thesis, Department of Dairy Science, Bangladesh Agricultural University, Mymensingh.

Association of Official Agricultural Chemists (AOAC). 2003. Official methods of analysis, (17* edition) Washington D.C. U.S.A.

Asaduzzaman. 2000. To detect the adulteration of milk obtained from Bangladesh Agricultural University, Mymensingh dairy farm and local markets. M.S. Thesis, Department of Dairy Science, Bangladesh Agricultural University, Mymensingh.

Bari, A.K.M. 2001. Comparative study of platform tests on milk in the local markets and Bangladesh Agricultural University dairy farm. M. S. Thesis, Department of Dairy Science, Bangladesh Agricultural University, Mymensingh.

BSTI, 2002. BDS 1702: Bangladesh standard: Specification for pasteurized milk. Bangladesh Standards and Testing Institution, Tejgaon Industrial Area, Dhaka, pp: 2-3.

Eckles, C.H., Cobms, W.B. and Macy, H. 1951. Milk and milk products. $4^{\text {th }}$ edition, Mcgarh-Hill Book Company, Newyork. pp. $49-57$. U.S.A.

Goff, H.D. and AR. Hill, 1993. Dairy Chemistry and Physics. In: Dairy Science and Technology Handbook I. Principles and Properties (Hui). VCH Publishers, New York, pp: I-81.

Haasnoot, W., Smits, N.G.E., Kemmers Voncken, A.E.M. and Bremer, M.G.E. 2004. Fast biosensor immunoassays in milk of ewes and goats. Journal of Dairy Science, 71:322-329.

Herreid, E.O. 2008. The Babcock test; A Review of the literature. Journal of Dairy Science. 25(4):342-343. 
Horwitz, W. 1975. Official Methods of Analysis of the Association of Official Analytical Chemists. Association of Official Analytical Chemists, Washington, DC, 259.

Hossain, M.S. 2009. Effect of milk production and milk composition of early lactating cows by supplementation of rice powder with concentrate. M. S. Thesis, Department of Dairy Science, BAU, Mymensingh.

Islam, M.N., Hussain, S.M.I. and Mannan, A.K.M. 1984. Studies on the physical parameters and chemical qualities on market milk in Mymensingh town (Bangladesh). Bangladesh Journal of Animal Science. 13 (1\&2): 52-55.

Islam, M.R. 2006. Milk yield and quality of different genotype of dairy cows of BAU dairy farm. M.S. Thesis, Department of Dairy Science, BAU, Mymensingh.

Lateef, M., Faraz, A., Mustafa, M.I., Akthar, P. and Bashir, M.K. 2009. Detection of adulterants and chemical composition of milk supplied to canteens of various hospitals in Faisalabad city. Pakistan Journal of Zoology. 9: 139-142.

Neumann, O.G., Harris and Rogers, 2002. Contribution of animal source of foods in improving diet quality and function in Children in the developing World. Nutr. Res., 22: 193-220.

Yadav, A.N. and Saraswat, B.L. 1982. Note on the physical and chemical qualities of market milk in Varanasi Town. Indian Journal of Research. 1(1): 74-76. 